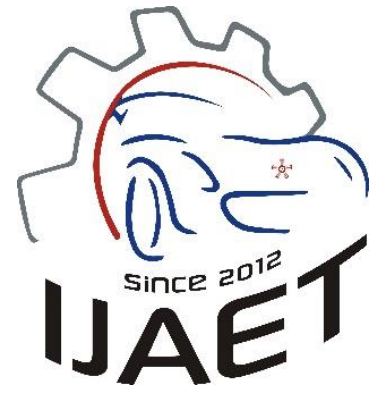

e-ISSN: 2146 - 9067

International Journal of Automotive

Engineering and Technologies

journal homepage: http://ijaet.academicpaper.org

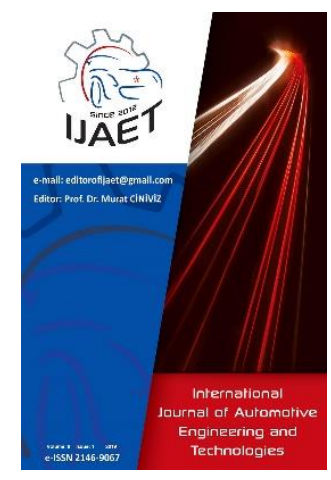

Original Research Article

\title{
Performance, emission, energetic and exergetic analyses of a compression ignition engine fuelled with sunflower oil methyl esters
}

\section{Tayfun ÖZGÜR ${ }^{1}$}

${ }^{1}$ Çukurova University, Engineering Faculty, Automotive Engineering Department, Adana, Turkey

\author{
ARTICLE INFO \\ * Corresponding author \\ tozgur@cu.edu.tr \\ Received: Feb 08, 2019 \\ Accepted: July 31, 2019 \\ Published by Editorial Board \\ Members of IJAET \\ C This article is distributed by \\ Turk Journal Park System under \\ the CC 4.0 terms and conditions.
}

\begin{abstract}
In this study, performance and emission characteristics of sunflower oil methyl esters (sunflower oil biodiesel/SOB) and diesel were studied in between 14002600 engine speed. After determining fuel properties, performance and emissions of the test engine, energy and exergy analysis were conducted by using experimental data attained from the experiments. Analyses were performed at $1800 \mathrm{rpm}$ (revolutions per minute) engine speed which gave maximum torque value. With the aid of experimental data and energy balances and exergy rates for the determined control volume which is the whole engine, first and second law efficiencies related with namely quantity and quality were determined for the test fuels, SOB and diesel fuel. Conclusions were evaluated to determine the effects of test fuels on $1^{\text {st }}$ law and $2^{\text {nd }}$ law efficiency performance.

Keywords: Diesel; Biodiesel; Energy; Exergy; Engine performance
\end{abstract}

\section{Introduction}

Nowadays, biodiesel is the most used alternative fuel instead of petroleum-based fuels. It is produced from renewable biomass, such as waste oils, vegetable oils or animal fats. The main advantages of biodiesel usage over conventional fossil-based fuels are being nontoxic, biodegradable, and environmentally beneficial [1]. However, with these significant advantages, biodiesel usage also causes SOB negative consequences. Biodiesel fuels generally have about $10-12 \%$ less energy content in comparison with fossil diesel on the mass basis. High price, injector coking, higher viscosity, engine compatibility, and engine wear are the other major disadvantages of biodiesel usage as fuel [2]. Many studies have been conducted in order to determine the characteristics of performance and emission of the compression ignition engines fueled with various biodiesel [3-7].

The efficiency and the performance of internal combustion engines (ICE) can be enhanced by controlling the combustion, proper thermal insulation and recuperation of the engine. From this point of view, the efficiencies of ICEs operating with alternative fuels, in the means of energy and exergy is very crucial [8]. There are SOB studies which used just the first law of thermodynamics to determine performance parameters of the engine. However, to evaluate the energy resource utilization, using just the 
first law of thermodynamics is not enough. The second law of the thermodynamics is essential to be able to understand the complete system thermodynamics and to determine magnitudes, locations, and causes of energy waste in a thermal system [9]. There are SOB studies which contain exergy analyses of the ICEs. [1012].

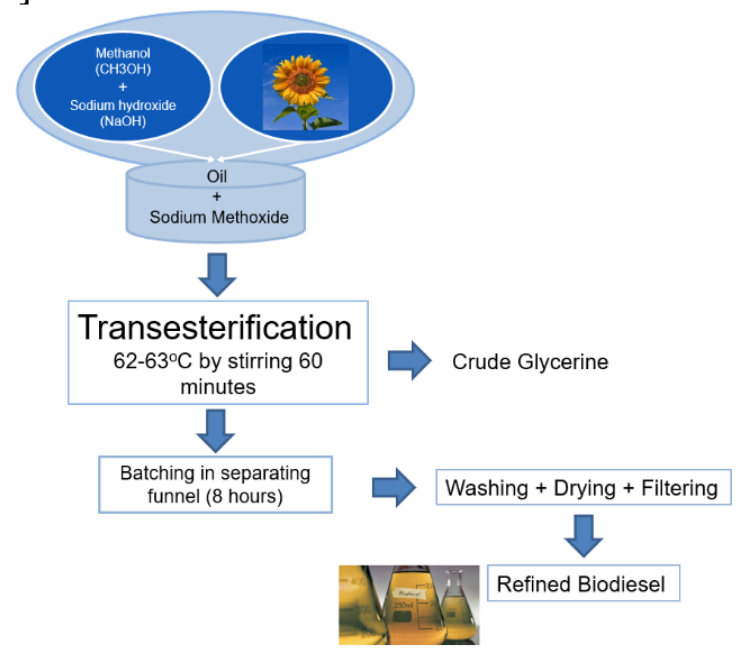

Figure 1. Biodiesel Production Processes

In this study, characteristics of the test engine which is a diesel engine fueled with SOB and

conventional diesel fuel in the means of performance and emission were determined and compared. After this step, energy and exergy analysis were conducted by using the extracted data from the experiments to be able to define energetic and exergetic performance of the test engine.

\section{Material and Method}

\subsection{Biodiesel Production and Specifications}

Experiments were carried out in Department of Automotive Engineering Laboratories in Çukurova University, Adana, Turkey.

The transesterification of SOB biodiesel was illustrated in Figure 1.

The analysis of test fuels was conducted at the Çukurova University Automotive Engineering Laboratories. Density, kinematic viscosity, flash point, cetane number, pour point, heating value characteristic was tested according to standards. Fuel properties of diesel and biodiesel fuels were given in Table 1. Also European petrodiesel standard EN 590 and European biodiesel standard EN 14214 was given in Table 1 .

\begin{tabular}{lcccc}
\hline \multicolumn{1}{c}{ Properties } & Diesel Fuel & EN 590 & Sunflower Oil Biodiesel & EN 14214 \\
\hline Density $\left(\mathrm{kg} / \mathrm{m}^{3}\right)$ & 833 & $820-845$ & 887 & $860-900$ \\
Pour Point $\left({ }^{\circ} \mathrm{C}\right)$ & -10 & - & 1 & Summer $<4$, \\
Flash Point $\left({ }^{\circ} \mathrm{C}\right)$ & 58.5 & Min. 55 & 162 & Winter $<-1$ \\
Cetane Number & 56 & Min. 51 & 54 & Min 120 \\
Kinematic Viscosity $\left(\mathrm{mm}^{2} / \mathrm{s}\right)$ & 2.85 & $2-4.5$ & 4.59 & Min. 51 \\
Heating Value $(\mathrm{kJ} / \mathrm{kg})$ & 42980 & - & 38898 & $3.5-5$ \\
\hline
\end{tabular}

Table 2. Technical specifications of the engine

\begin{tabular}{ll}
\hline Specification & Description \\
\hline Brand and Model & Mitsubishi Canter 4D34-2A \\
Type and The Configuration & Direct Injection - In line 4 \\
Displacement & $3907 \mathrm{cc}$ \\
Bore - Stroke & $104 \mathrm{~mm}-115 \mathrm{~mm}$ \\
Max Power and Torque & $89 \mathrm{~kW} @ 3200 \mathrm{rpm}-295 \mathrm{Nm} @ 1800 \mathrm{rpm}$ \\
Cooling & Water cooled \\
Weight & 325 \\
\hline
\end{tabular}

\subsection{Engine Test Rig}

Engine performance tests were performed on a commercial four cylinder, four-stroke, naturally aspirated, water-cooled direct injection diesel engine with a $89 \mathrm{~kW}$ maximum power at 3200 rpm engine speed and has $295 \mathrm{Nm}$ maximum torque at $1800 \mathrm{rpm}$ engine speed. Technical specifications of engine were given in Table 2 . Before the tests, the engine was run for 10 minutes with diesel fuel to attain the operation temperature. Test fuels were examined from 1000 to $3000 \mathrm{rpm}$ with a range of $200 \mathrm{rpm}$ at full load condition.

Torque and power output were quantified with the aid of hydraulic dynamometer. Schematic representation of experimental setup was showed in Figure 2. The speed sensor is used to determine the engine speed. Torque of dynamometer is quantified by the help of $S$ type 
load cell. Dynamometer control panel and computer was utilized for recording all the data that was produced by the system.

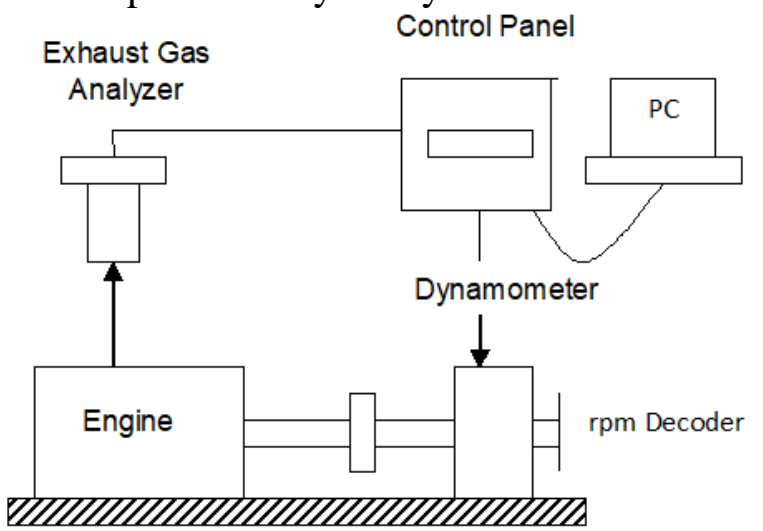

Figure 2. Schematic representation of experimental setup

TESTO $350 \mathrm{XL}$ gas analyzer is utilized to quantify exhaust emissions. Emission data was recorded by means of computer program. Measurement accuracy of the gas analyzer is $\pm 10 \mathrm{ppm}$ for $\mathrm{CO}, 1 \%$ for $\mathrm{CO} 2$ and $\pm 1 \mathrm{ppm}$ for NOx. Measurement capacity of the device is 0 $10000 \mathrm{ppm}$ for $\mathrm{CO}, 0-50 \%$ for $\mathrm{CO} 2$ emission and $0-3000 \mathrm{ppm}$ for NOx.

\section{Results and Discussion}

\subsection{Brake Power and Torque}

The alteration of the brake power and torque values of the test fuels at different engine speeds are illustrated in the following figures, figures 3 and 4. It is clear that both the values of the brake power and torque values of the test engine were reduced by using biodiesel. There was nearly $4.8 \%$ decrement in brake power and 5.4\% decrement in torque values when the engine was operated with SOB instead of the diesel fuel. Lower engine power can be explained by lower energy content and poor atomization because of higher density and viscosity values of SOB.

\subsection{Emissions}

$\mathrm{CO}$ emission results of the experiments at different engine speed for fuels was compared in Figure 5. Incomplete combustion is the main reason for $\mathrm{CO}$ emission in engine. With the usage of biodiesel, $\mathrm{CO}$ emission was decreased by $5.7 \%$ with respect to diesel fuel. Extra oxygen content of biodiesel provides extra oxidation of $\mathrm{CO} . \mathrm{CO}_{2}$ emission was increased by using $\mathrm{SOB}$ with respect to diesel fuel as anticipated. When biodiesel was used, oxygen content of the combustion chamber increased. Therefore, this extra oxidation effect of biodiesel caused to increase $\mathrm{CO}_{2}$ emission. With the biodiesel usage, $\mathrm{CO}_{2}$ emission was increased by $5.4 \%$ with respect to diesel fuel. It was shown in Figure 6. Temperature is the most important parameter to form oxides of nitrogen $\left(\mathrm{NO}_{\mathrm{x}}\right)$. Figure 7 showed that biodiesel increased the content of nitric oxide emission as compared to standard diesel. The content of oxygen of biodiesel enhances the combustion. Enhanced combustion means higher end-combustion temperatures. Therefore, when biodiesel was used, $4.8 \%$ increment of $\mathrm{NO}_{\mathrm{x}}$ emission was obtained.

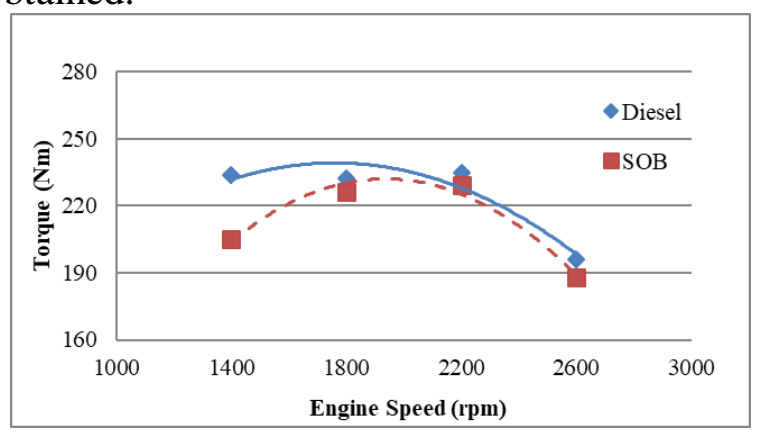

Figure 3. Torque versus engine speed

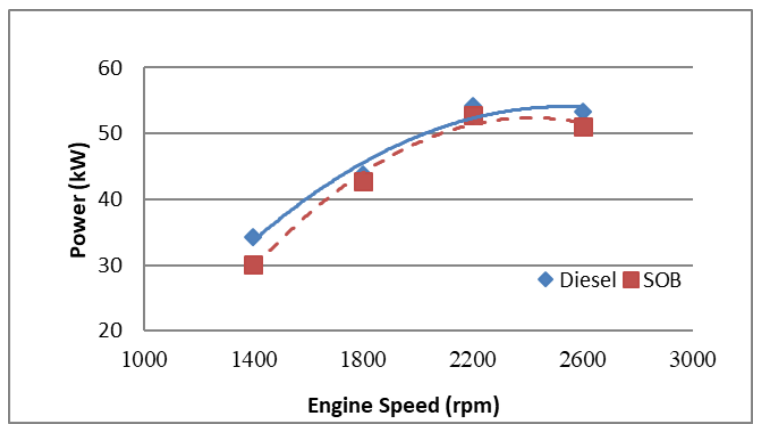

Figure 4. Brake power versus engine speed

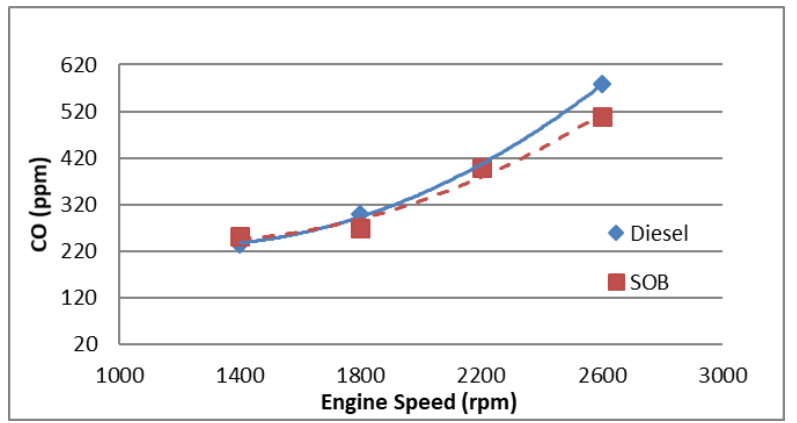

Figure 5. Carbon monoxide versus engine speed

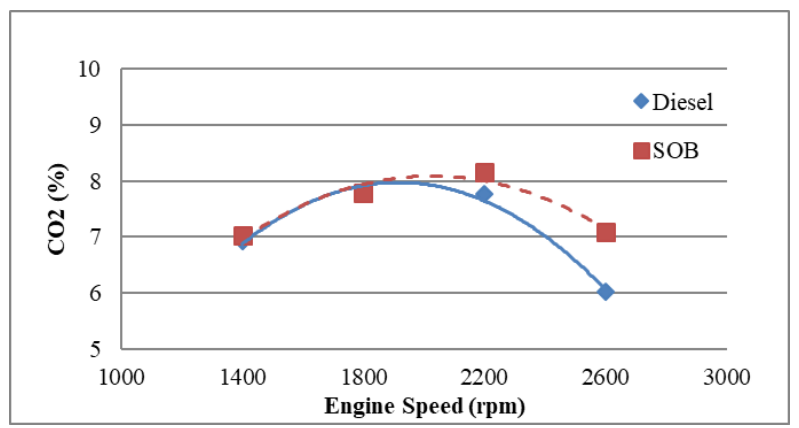

Figure 6. Carbon dioxide versus engine speed 


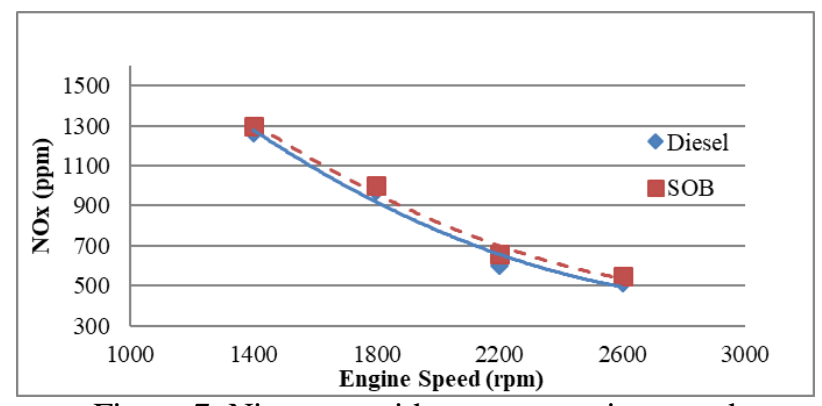

Figure 7. Nitrogen oxides versus engine speed

\subsection{Energetic and Exergetic Performance}

Energy is inevitable part of life and industrialization. Therefore, usage of energy sources effectively and efficiently is very important issue. For welfare and composure of human, there is need for energy usage on every sector [13].

To be able to perform energy and exergy analyses, general form of chemical reaction was considered as:

$$
\begin{aligned}
a \mathrm{C}_{x} \mathrm{H}_{y} \mathrm{O}_{z}+b\left(\mathrm{O}_{2}+3.76 \mathrm{~N}_{2}\right) \rightarrow c \mathrm{O}_{2} & +d \mathrm{CO}+e \mathrm{CO}_{2}+f \mathrm{NO} \\
& +g \mathrm{gNO}_{2}+h \mathrm{~N}_{2}+j \mathrm{H}_{2} \mathrm{O}
\end{aligned}
$$

By applying conservation of mass principle and using emission data procured from tests, all coefficients were found.

The assumptions made in the energy and exergy analyses are described below:

$\checkmark \quad$ Whole engine is considered as control volume and it operates as a steady state open system,

$\checkmark \quad$ The exhaust gas mixtures and the combustion air $\left(79 \% \mathrm{~N}_{2}, 21 \% \mathrm{O}_{2}\right)$ are ideal,

$\checkmark \quad$ The potential and kinetic energy effects of combustion air, fuel stream and exhaust gases are ignored,

$\checkmark \quad$ The reference environment is, $\mathrm{P}_{0}=1 \mathrm{~atm}$ and $\mathrm{T}_{\mathrm{o}}=25^{\circ} \mathrm{C}$ [14].

The balances of mass and for the control volume, steady state open system can be expressed as:

$$
\begin{aligned}
& \sum m_{\text {in }}=\sum m_{\text {out }} \\
& Q-W=\sum m_{\text {out }} h_{\text {out }}-\sum m_{\text {in }} h_{\text {in }}
\end{aligned}
$$

Energy input rate $\left(E_{f u e l}\right)$ can be found as:

$$
E_{\text {fuel }}=m_{\text {fuel }} H_{u}
$$

Energy efficiency ( $1^{\text {st }}$ law efficiency) is computed by dividing the work rate to the energy input rate of fuel;

$$
\eta_{l}=\frac{W}{E_{\text {fuel }}}
$$

Energy input rate is the energy supplied to the engine that contains work rate and heat losses and computed by multiplying mass flow rate with lower heating value of fuel. Given energy to engine is directly in proportion with lower calorific value of fuel. Therefore, being heating value of diesel fuel is high caused to have higher energy input rate of this fuel. It is clearly seen from the Figure 8 that, diesel fuel supplied 1.4\% more energy to control volume according to SOB. Figure 9 shows energetic efficiencies of engine by using diesel and SOB at $1800 \mathrm{rpm}$ engine speed by comparison. Usage of diesel fuel causes more efficient conversion as indicated in the figure. 1st law efficiency of the SOB is $1.05 \%$ lower than diesel fuel. Cetane number of diesel fuel and SOB are 56 and 54, respectively. Since cetane number can be seen as an indicator of the combustion speed of diesel fuel; thanks to high cetane number, combustion occurs highly efficiently.

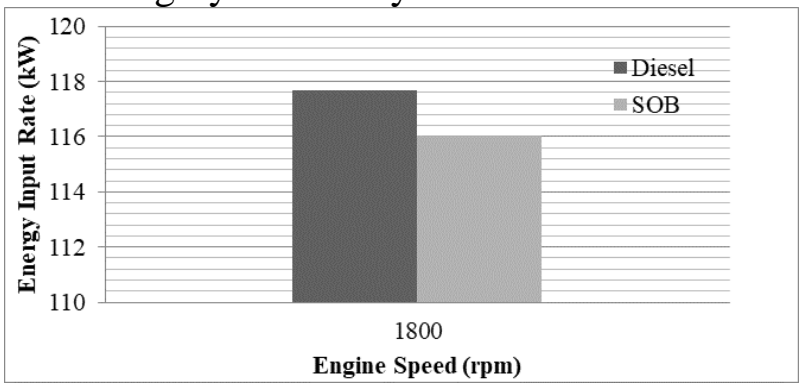

Figure 8. Energy input rate versus engine speed

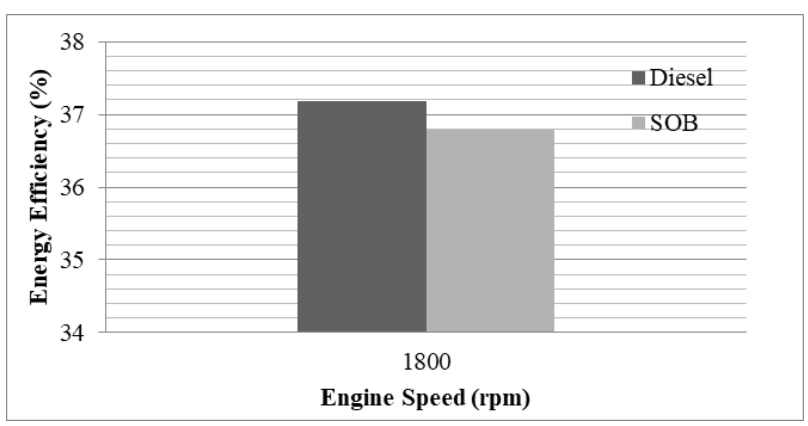

Figure 9. Energy efficiency versus engine speed

The exergy balances for the control volume, steady state open system can be written as:

$$
\sum m_{\text {in }} \varepsilon_{\text {in }}=\sum m_{\text {out }} \varepsilon_{\text {out }}+E x_{\text {heat }}+E x_{\text {work }}+E x_{\text {dest }}
$$

Input exergy rate contains only chemical exergy of the fuel. Thermomechanical exergy of fuel and total exergy of air can be neglected. Molecular formulas of sunflower oil biodiesel and diesel fuel were considered as $\mathrm{C}_{20} \mathrm{H}_{38} \mathrm{O}_{2}$ [15] and $\mathrm{C}_{14} \mathrm{H}_{25}$ [16], respectively.

$$
E x_{\text {in }}=m_{\text {fuel }} \varepsilon_{\text {fuel }}
$$




$$
\begin{aligned}
& \varepsilon_{\text {fuel }}= H_{u} \varphi \\
& \varphi=1.041+0.1728 \frac{h}{c}+0.0432 \frac{o}{c} \\
&+0.2169 \frac{\alpha}{c}\left(1-2.0628 \frac{h}{c}\right)
\end{aligned}
$$

where $\mathrm{h}, \mathrm{c}, \mathrm{o}, \alpha$ represents mass fractions of hydrogen, carbon, oxygen, sulfur contents.

Exergy efficiency ( $2^{\text {nd }}$ law efficiency) can be found by dividing the exergy work rate to the energy input rate of the fuel.

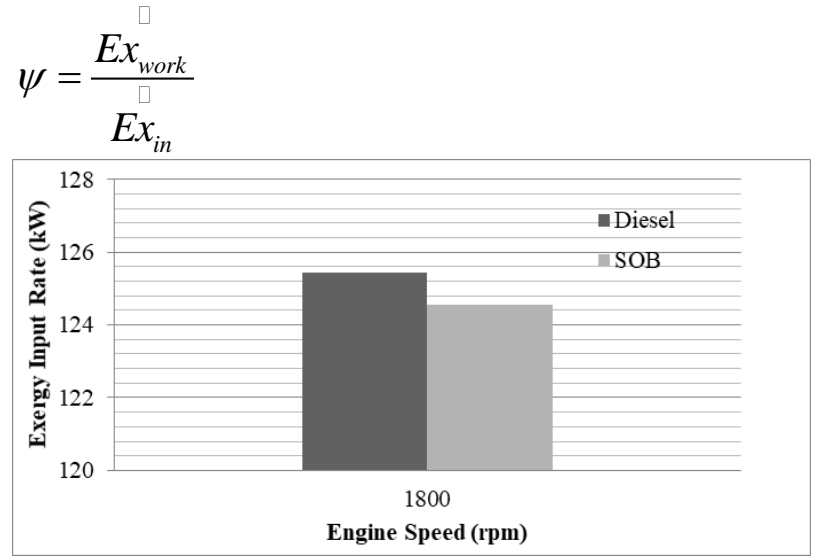

Figure 10. Exergy input rate versus engine speed

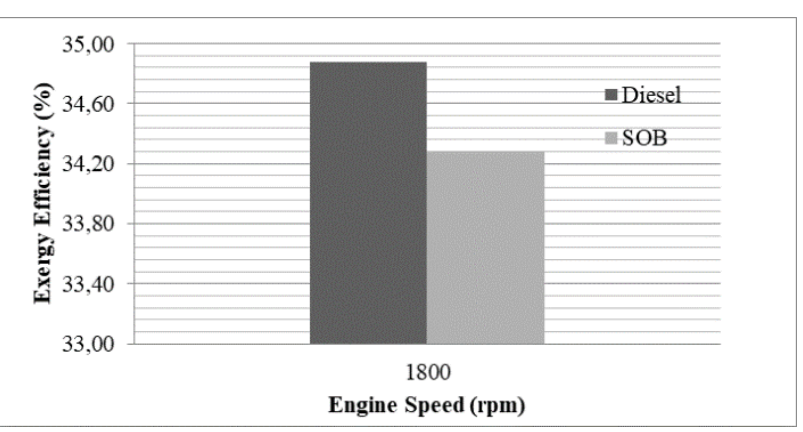

Figure 11. Exergy efficiency versus engine speed

Figure 10 demonstrates fuel exergy at a specific engine speed by comparison. Same tendency with energy input rates of fuels was attained as anticipated because the term specific flow exergy in input exergy rate includes lower calorific value of fuel. SOB has $0.7 \%$ lower input exergy rate value than diesel fuel. Figure 11 shows exergetic efficiencies of engine by using diesel and SOB at $1800 \mathrm{rpm}$ engine speed by comparison. Exergy efficiency of the SOB is $1.73 \%$ lower than diesel fuel. SOB has extra oxygen content. That means obtaining higher end-combustion temperature in combustion chamber. Higher end-combustion temperature triggers the destruction of exergy. There is a reverse tendency between exergetic efficiency and exergy destruction. That's way biodiesel showed lower exergetic performance.

\section{Conclusions}

In this study, besides performance and emission characteristics, $1^{\text {st }}$ law and $2^{\text {nd }}$ law efficiencies of a compression ignition engine operated with diesel and SOB were achieved.

The main conclusions of study were presented as:

- $\quad$ The power and torque output of engine was decreased by $4.8 \%$ and $5.4 \%$, respectively with use of biodiesel.

- $\quad \mathrm{CO}$ emission values improved (5.7\%) whereas $\mathrm{NOx}(4.8 \%)$ and $\mathrm{CO} 2(5.4 \%)$ values raised with biodiesel usage against diesel fuel.

- Diesel fuel indicated better performance than SOB in terms of the $1^{\text {st }}$ law and $2^{\text {nd }}$ law efficiencies.

- $\quad$ Energy and exergy efficiency values were reduced by $1.05 \%$ and $1.73 \%$ by use of SOB according to diesel fuel.

Destruction of exergy caused by irreversible processes (mainly by combustion) is the most important factor of system inefficiency.

\section{References}

1. Ozcanli, M., Gungor, C., Aydin, K. Biodiesel Fuel Specifications: A Review. Energy Sources, Part A: Recovery, Utilization, and Environmental Effects. vol. 35, pp. 635647, 2013.

2. Tuccar, G., Tosun E., Ozgur, T., Aydin, $\mathrm{K}$. Diesel engine emissions and performance from blends of citrus sinensis biodiesel and diesel fuel. Fuel. vol. 132, pp. 7-11, 2014.

3. Canakci M., Van Gerpen JH. Comparison of engine performance and emissions for petroleum diesel fuel, yellow grease biodiesel and soybean oil biodiesel. Trans Am Soc Agric Eng. vol. 46, pp. 937-944, 2003.

4. Canakci M. Performance and emissions characteristics of biodiesel from soybean oil. Part D: J Automob Eng. vol. 219, pp. 915-922, 2005.

5. Agarwal AK, Das LM. Biodiesel development and characterization for use as a fuel in compression ignition engines. Am Soc Mech Eng J Eng Gas Turbines Power. vol. 123, pp. 440-447, 2000.

6. Srinivas Rao P, Gopal Krishna KV. Vegetable oils and their methyl esters as fuels for diesel engines. Indian J Technol. Vol. 29, 
pp.121-134, 1991.

7. Ozcanli, M., Serin, H., Saribiyik, O.Y., Aydin K., Serin, S. Performance and Emission Studies of Castor Bean (Ricinus Communis) Oil Biodiesel and Its Blends with Diesel Fuel. Energy Sources, Part A: Recovery, Utilization, and Environmental Effects. vol. 34, pp. 18081814, 2012.

8. Tat, M.E., Cetane number effect on the energetic and exergetic efficiency of a diesel engine fuelled with biodiesel. Fuel Processing Technology. vol. 92, pp. 1311-1321.

9. Canakci, M., Hosoz M. Energy and Exergy Analyses of a Diesel Engine Fuelled with Various Biodiesels. Energy Sources, Part B. vol. 1, pp. 379-394, 2006.

10. Kopac M., Kokturk, L. Determination of optimum speed of an internal combustion engine by exergy analysis. Int. J. Exergy. vol. 2, pp. 40-54 .2005.

11. Caliskan, H., Tat, ME., Hepbasli, A., Van Gerpen, J. Exergy analysis of engines fuelled with biodiesel from high oleic soybeans based on experimental values. Int. J. Exergy. vol. 7, pp. 20-36, 2010.

12. Caliskan, H., Tat, ME., Hepbasli, A. A review on exergetic analysis and assessment of various types of engines. Int. J. Exergy. vol. 7, pp. 287-310, 2010.

13. Tosun, E. Energy and Exergy Analysis of a Diesel Engine, Çukurova University, MSc thesis, 2013, Adana, Turkey.

14. Moran, M.J., Shapiro, H.N. Fundamentals of Engineering Thermodynamics. John Willey \& Sons, New York, 2000.

15. Madyira, D.M., Zanele N., Akinlabi, E.T. Characterizing Sunflower Oil Biodiesel Blends as Alternatives to Fossil Diesel. Proceedings of the World Congress on Engineering. Vol. 3, London, U.K.

16. Allen, C.M., Toulson, E., Hung, D.L.S., Schock, H., Miller, D., Lee, T. Ignition Characteristics of Diesel and Canola Biodiesel Sprays in the Low-Temperature Combustion Regime. Energy\&Fuels, Vol. 25, pp. 28962908, 2011. 